\title{
Mixed outcomes from conservation practices on soils and Striga-affected yields of a low-input, rice-maize system in Madagascar
}

\author{
Jonne Rodenburg ${ }^{1,2}$ (D) Meva Tahiry Randrianjafizanaka ${ }^{3} \cdot$ Lucie Büchi $^{2} \cdot$ Ibnou Dieng $^{1,4} \cdot$ Alain Paul Andrianaivo $^{5}$. \\ Lala Harivelo Raveloson Ravaomanarivo ${ }^{3}$. Patrice Autfray ${ }^{6}$
}

Accepted: 30 January 2020 / Published online: 18 February 2020

(C) The Author(s) 2020

\begin{abstract}
On upland soils in tropical Africa, common production constraints of rice and maize on smallholder farms are poor soil fertilityresulting from soil erosion and nutrient depletion — and infestation by witchweeds (Striga spp.). In Madagascar where these crops are often grown in rotation, combining legume cover crops with no-till and crop residue mulching-labelled conservation agriculture (CA) - may address these problems. Previously, it was shown that CA practices contribute to steep reductions in Striga asiatica infection. In the current study, a 4-year field experiment was conducted to test, for the first time, the hypothesis that CA practices also contribute to crop yield and soil improvements under Striga-infested conditions. The conventional mono-crop rice-maize rotation practice, involving seasonal tillage and crop residue removal, was compared to three rice-maize rotation systems following CA practices, each with a different legume cover crop option: (1) two short-cycle annual species, cowpea (Vigna unguiculata) and mucuna (Mucuna pruriens); (2) a long-cycle annual, ricebean (Vigna umbellata); and (3) a perennial, stylosanthes (S. guianensis). Rice yields, as well as yield variability, generally increased by changing from the conventional to a CA practice, and maize yields were variable and low in particular under the CA practices. CA practices significantly reduced soil displacement by rainwater runoff and increased soil nitrogen and $\mathrm{pH}$ levels $(0-20 \mathrm{~cm}$ depth), in particular with stylosanthes as cover crop, but did not result in a significant change in soil organic carbon concentration. Rice yields correlated negatively with Striga asiatica plant numbers in years with moderate infection levels. This is the first study that shows mixed outcomes from CA practices in tropical cereal rotation systems on degraded, Striga-infested soils, and subsequent entry points for system improvements. Suggested improvements include judicious cover crop management, complementary fertilizer applications and selection of competitive, resistant and adapted crop varieties.
\end{abstract}

Keywords Conservation agriculture $\cdot$ Soil conservation $\cdot$ Oryza sativa $\cdot$ Zea mays $\cdot$ Striga asiatica

Jonne Rodenburg

j.rodenburg@greenwich.ac.uk

1 Africa Rice Center, 01 B.P. 2551, Bouake, Côte d'Ivoire

2 Present address: Natural Resources Institute (NRI), University of Greenwich, Chatham Maritime, Kent ME4 4TB, UK

3 Faculté des Sciences, Université d'Antananarivo, BP 906, Antananarivo, Madagascar

4 Present address: International Institute for Tropical Agriculture (IITA), PMB 5320, Oyo Road, 200001, Ibadan, Nigeria

5 Centre National de la Recherche Appliquée au Développement Rural (FOFIFA), BP 1444, Antananarivo, Madagascar

6 CIRAD, UPR AIDA, F-34398, Montpellier, France

\section{Introduction}

Rice (Oryza sativa L. and O. glaberrima Steud.) and maize (Zea mays L.) are among the main staple cereal crops in Africa, but yields on smallholder farms are often low (Shiferaw et al. 2011; Seck et al. 2012). Average rain-fed maize yields in Africa range between 1.2 and $2.2 \mathrm{t} / \mathrm{ha}$, and the average gap between water-limited and actual yields of maize is $3.7 \mathrm{t} / \mathrm{ha}$ (van Ittersum et al. 2016). Average yields of rain-fed upland rice in Africa range from 1.0 to $2.5 \mathrm{t} / \mathrm{ha}$ (Tanaka et al. 2017), and attainable yield gains of up to 2.9 t/ha have been estimated (Nhamo et al. 2014). Poor soil fertility - often resulting from soil erosion and continuous cropping without nutrient replenishment — and infestation by 
parasitic weeds of the Striga genus are important reasons for the low yields of both crops on this continent (Shiferaw et al. 2011; Nhamo et al. 2014). Smallholder rice-maize production systems in Madagascar are exemplary of this situation. There, farmers rotate upland rice with maize at mid and high altitudes, on poor and erosive soils (Dusserre et al. 2012) that are heavily infested by Striga asiatica (L.) Kuntze. If uncontrolled, this parasitic weed causes average yield losses of $73 \%$ in rice (Rodenburg et al. 2016) and $80 \%$ in maize (Rusinamhodzi et al. 2012).

Several agronomic practices may address these biophysical production constraints. Erosion can be reduced by covering the soil with living or dead vegetative biomass, and by reducing disturbance induced by tillage (e.g. Schuller et al. 2007). Soil fertility - in particular organic carbon concentrationcan also be improved by permanent vegetative soil coverage (i.e. cover crops and mulch), through decomposition of organic material (e.g. Barthes et al. 2004). Cover crops further enhance soil fertility if nitrogen-fixing legume species are used, provided that their efficiency is not limited by drought or $\mathrm{P}$ or $\mathrm{K}$ deficiencies (Vanlauwe and Giller 2006). Intercropped legumes could function as a trap crop for Striga spp., and thereby reduce infection levels to the main crop (e.g. Randrianjafizanaka et al. 2018).

The combination of no-till with permanent soil coverage by legume intercropping and crop residue mulching is compliant with conservation agriculture (e.g. Vanlauwe et al. 2014). In Madagascar, it was recently shown that a conservation agriculture (CA) approach gradually increases crop yields (Bruelle et al. 2015) and, with sufficient crop residue mulch, reduces weed biomass (Ranaivoson et al. 2019). Another recent study from Madagascar showed that CA practices can reduce infection levels of the parasitic weed Striga asiatica, both in rice and maize (Randrianjafizanaka et al. 2018). The objectives of the current study are to assess concomitant yield and soil benefits of CA practices under such Striga-infested conditions and to find entry points for technological improvements of this cropping system. The research questions addressed are (1) whether rice and maize yields can be increased by CA practices, under Striga-infested conditions, and (2) whether CA practices can contribute to improved soil fertility and soil conservation. To this end, a 4-year and multi-factorial field experiment was established in central Madagascar, in an important rice-maize production area at medium to high altitudes, where Striga asiatica is prevalent (Fig. 1a).

\section{Materials and methods}

\subsection{Study site}

The experiment, starting in October 2011, was conducted in a farmer's field in Ivory $\left(19^{\circ} 33^{\prime} 26^{\prime \prime} \mathrm{S}\right.$ and $\left.46^{\circ} 24^{\prime} 55^{\prime \prime} \mathrm{E}\right)$ at
$930 \mathrm{~m}$ above sea level (Fig. 1a). The field was selected as representative cropping environment for central Madagascar, with typical soil and landscape characteristics and Striga asiatica infestation. Two years prior to the start of the experiment, the farmer put the field under fallow due to a severe infestation by $S$. asiatica. Previously, the field was grown to maize. The field was located on a moderate slope $(<5 \%)$. The soil was characterized as Oxisol (USDA). At the onset of the experiment, the topsoil layer $(0-10 \mathrm{~cm})$ properties were clay:silt:sand composition 34:39:27, $\mathrm{pH}\left(\mathrm{H}_{2} \mathrm{O}\right) 5.3$, soil organic C concentration (Walkley-Black) $17.2 \mathrm{~g} / \mathrm{kg}$, total N concentration (Kjeldahl) $1.4 \mathrm{~g} / \mathrm{kg}$ and available-P concentration (Olsen) $2.5 \mathrm{mg} / \mathrm{kg}$.

Ivory has a tropical climate with the main rainy season from November to April. Across the 4 years of the experiment, temperatures ranged between $17^{\circ} \mathrm{C}$ (night) and $31^{\circ} \mathrm{C}$ (day), while monthly averages ranged between 21 and $25^{\circ} \mathrm{C}$. The seasonal rainfall (September to May) during the 4 years ranged between $976 \mathrm{~mm}$ (2011-2012) and $1814 \mathrm{~mm}$ (20142015), while the 11-year mean seasonal rainfall is around $1307 \mathrm{~mm}$ (Randrianjafizanaka et al. 2018).

\subsection{Experimental design, treatments and plot sizes}

The experiment was laid out as a randomized complete block design with four cropping practices and six replicates and run for four rainy seasons (one season per year). Each replicate comprised two halves, with rice in one half and maize in the other, randomly assigned. This set-up enabled yearly observations in each crop of the rotation (Fig. 1b). The four treatments were as follows: (1) a rice mono-crop in annual rotation with a maize mono-crop following conventional seasonal soil tillage (0-15 cm depth) and crop residue removal (CONV); (2) a rice mono-crop in annual rotation with maize intercropped with two short-cycle annual legumes, cowpea and mucuna (CACM); (3) a rice mono-crop in annual rotation with maize intercropped with a long-cycle annual legume, ricebean (CARB); and (4) rice intercropped with the perennial legume, stylosanthes, in annual rotation with maize intercropped with stylosanthes (CAST). Treatments CACM, CARB and CAST followed conservation agriculture (CA) principles, and therefore, the soil was tilled only prior to the first year and thereafter each crop was sown by direct drilling while crop residues (everything except the grains, rachis, cobs and pods) were not removed but rather used as mulch to cover the soil. Crop vegetation was cut at ground level and spread evenly over the soil without further cuttings. The position of the treatments (cropping practices) in each block was randomized once, in year 1, and maintained for the following years (2-4) while the same plot received the same crop every 2 years (Fig. 1b).

The plot size, representing a treatment, was $90 \mathrm{~m}^{2}(5 \times$ $18 \mathrm{~m}$ ). For grain yield and biomass assessment of crops and legumes, and for $S$. asiatica plant counts, a central area was 
Fig. 1 Aerial photo of the experiment in Ivory, Madagascar. Mulched soils clearly differentiate from soils without mulch. This picture further shows the typical landscapes in which rice and maize are cultivated in this area (a). Schematic presentation of the experiment, showing rice-maize rotation and cover crops, tillage operations, main sampling and observation timings (b)
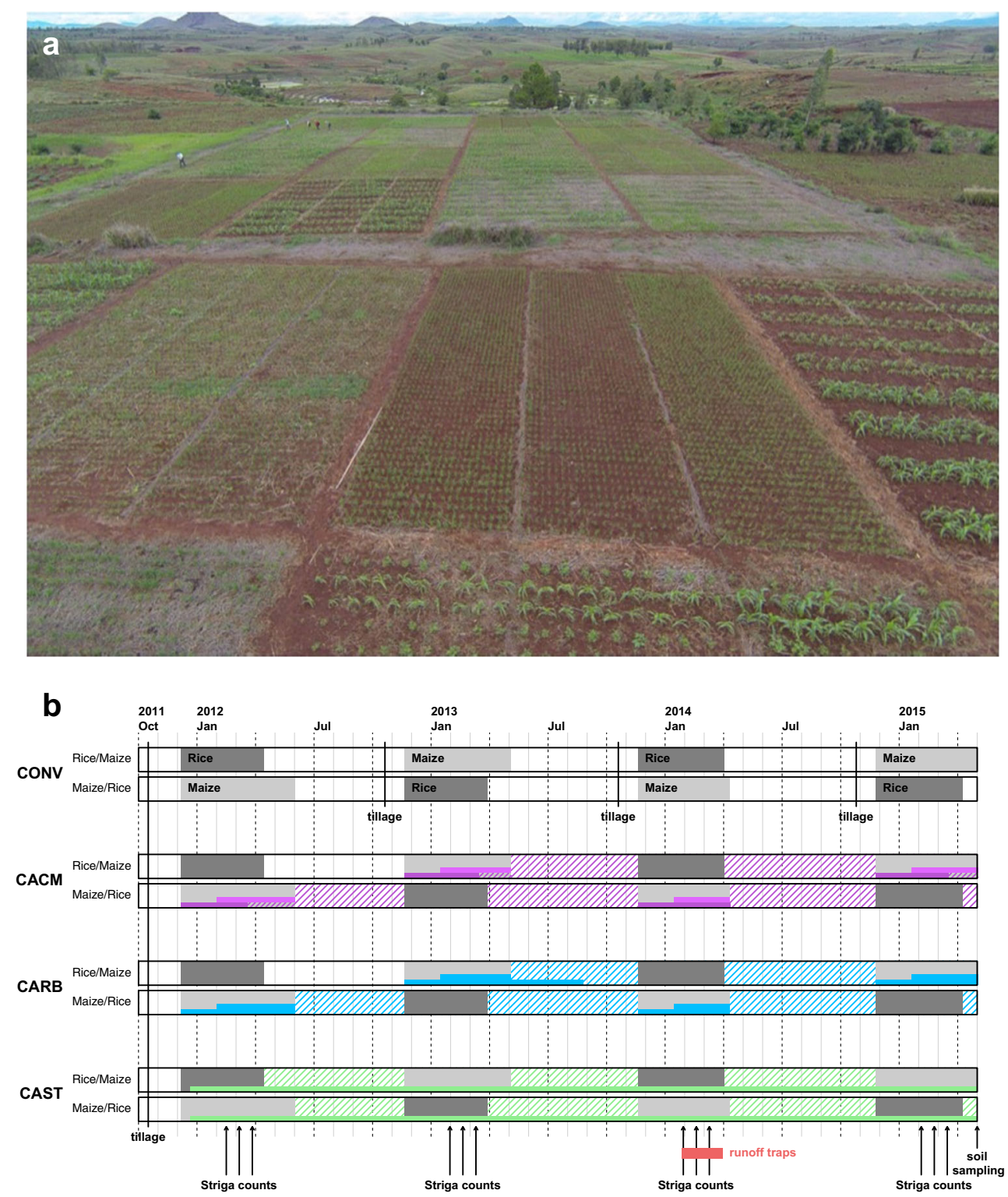

used in each plot. In rice plots, these net plots were $37.8 \mathrm{~m}^{2}$ $(4.2 \times 9 \mathrm{~m})$; in maize plots, these were $36 \mathrm{~m}^{2}(4 \times 9 \mathrm{~m})$. Two $3-$ $\mathrm{m}^{2}(0.6 \times 5 \mathrm{~m})$ areas, outside the crop assessment areas, were used for soil sampling.

\subsection{Plant material}

The rice (O. sativa, ssp. japonica) variety used for this experiment was B22, one of the most widely grown upland rice varieties in central Madagascar. Seeds were obtained from Cirad-Madagascar's breeding program. The maize variety in this study was the locally available high-yielding, openpollinated IRAT 200. Seeds were obtained from Ambatolahy, a nearby village. The legume cover crop varieties were (1) cowpea cv. David, a short-cycle (80 days) and erect variety; (2) mucuna cv. CTAS MU1, a medium-cycle
(150 days) and climbing variety; (3) ricebean cv. CTAS tsiasisa, a long-cycle (240-270 days) and climbing variety; and (4) stylosanthes, cv. CIAT 184. Cowpea seed was received from SDMad (seed multiplier centre) at Ambatondrazaka, mucuna seed was obtained from CTAS (Centre Technique d'Agroécologie du Sud) at Ambovombe, ricebean seed was obtained from a farmer at Fidirana and stylosanthes seed was obtained from a farmer at Mazoto.

\subsection{Field preparations and crop establishment}

In October 2011, the field was cleaned from fallow vegetation and ploughed using a tractor-mounted disc-plough (depth, $30 \mathrm{~cm}$ ). Ploughing was followed by harrowing using a tractor-mounted tooth-peg harrow to obtain a fine tilt. In the conventional tillage plots (CONV), seasonal tillage from the 
second season onwards was done manually with an angady, which is a local traditional soil tillage tool (depth, 10-20 cm).

Rice sowing was done manually between the end of November and the beginning of December, at a planting distance of $20 \mathrm{~cm}$ in the row and $30 \mathrm{~cm}$ between rows and a rate of 6-7 seeds per hill. Maize sowing was done manually between the end of November and mid-December in paired rows with $50 \mathrm{~cm}$ between two rows of one pair and $150 \mathrm{~cm}$ between two pairs, at a rate of two seeds per hill.

In CACM, cowpea was sown each season at the same time as maize, between two pairs of maize rows, at a rate of two seeds per hill and a plant distance of $25 \mathrm{~cm}$ in the row and $50 \mathrm{~cm}$ between the rows. One row of mucuna was sown between two pairs of cowpea and another row between two rows of a pair of maize, at a rate of two seeds per hill, at 50 to 60 days after seeding (DAS) of maize and cowpea. In CARB, ricebean was sown each season at the same time as maize with two rows of ricebean between two pairs of maize rows, at a rate of 5-7 seeds per hill and a planting spacing of $50 \mathrm{~cm}$ in the row and $50 \mathrm{~cm}$ between rows. An additional row of ricebean was sown between two pairs of maize rows, at 50 60 DAS. In CAST, in year 1, stylosanthes was sown at 14 DAS of rice and maize (independently) at a density of 30 by $40 \mathrm{~cm}$ in between the cereal crop at a seed rate of $5 \mathrm{~kg} / \mathrm{ha}$. To reduce competition, stylosanthes was rolled twice yearly using an oxen-drawn roller, during the non-crop period (MayNovember), and cut back prior to each new season. In the following seasons, stylosanthes was allowed to re-sprout from the lopped plants as well as from seeds produced and shed in the previous year.

Each season, fresh cattle manure (mixed with rice straw) was applied to both rice and maize at sowing. Manure was applied at the planting holes at a rate of 11 tons of dry matter (DM) per ha in rice, and 5.5 tons DM per ha in maize, following conventional local farmer practices. The nutrient concentration of cattle manure, assessed prior to year 4 , was $0.93 \%$ $\mathrm{N}, 11.9 \% \mathrm{C}, 0.14 \% \mathrm{P}, 0.94 \% \mathrm{~K}, 0.50 \% \mathrm{Ca}$ and $0.20 \% \mathrm{Mg}$. All weeds other than $S$. asiatica were removed by hand at $46-50$ and 74-85 DAS in each cropping season. Between the main crop harvest time and the start of the new season, apart from rolling stylosanthes, plots and crop residues were left untouched.

During all 4 years, the experiment was routinely managed and monitored by the same experienced field technician, while observations were done by the same researchers.

\subsection{Crop sampling}

Cereal grain yields were assessed at grain maturity: i.e. 117135 DAS for rice and 145-160 DAS for maize, depending on the year. Yield assessments were done from the central crop harvest areas. Rice panicles were cut and threshed by hand. This was followed by winnowing and air-drying of the grains for 5 days. Grain weight and moisture content were measured simultaneously, using a digital grain moisture meter of SATAKE (Model SS-7), to convert rice grain weights to $14 \%$ moisture content. For maize grain yield assessments, only cobs were harvested, and grains were removed by hand, followed by air-drying for 5 days and weighing. Maize grain weight at $14 \%$ moisture content was assessed as with rice.

Cereal and legume aboveground biomass dry weights (which did not include crop grains, pods, cobs and rachis) were assessed just after grain harvest from the same areas. Cowpea, mucuna and ricebean biomass were intertwined with maize. Therefore, for the biomass assessment (all aboveground parts, hand-cut at the soil surface level) of CACM and CARB, at harvest, all plant material (maize and legume) was combined. In the other CA plots (CAST), biomass of maize and stylosanthes was assessed separately, at the same time as the biomass dry weight assessments in CACM and CARB plots and the maize stover assessments in CONV plots. The biomass of stylosanthes was too bulky to assess from the whole harvest area and was therefore assessed from a randomly placed quadrat of $1 \mathrm{~m}^{2}$ in each harvest area. Stylosanthes biomass was extrapolated to the same area as the maize stover biomass coming from the same plots, and these were combined for comparison with other treatments.

Aboveground S. asiatica plant numbers were assessed at 70, 90 and 110 days after sowing (DAS) from the aforementioned central harvest areas.

\subsection{Assessment of soil erosion, soil sampling and analyses}

Topsoil displacement (henceforward referred to as 'erosion') was measured in year 3 (2013-2014), between 67 and 130 DAS (rainfall, $444 \mathrm{~mm}$ ), using a method described by Rodenburg et al. (2003). Two runoff traps per plot were installed in treatments representing contrasting conditions with respect to interrow soil coverage (no coverage, CONV; coverage by an annual cover crop, CARB; coverage by a perennial and prolific biomass producing cover crop, CAST) in all six replicates. Runoff traps were made of plastic bottles with a diameter of $9 \mathrm{~cm}$, by cutting off the tops at $30 \mathrm{~cm}$ height. These traps were inserted into the soil with the rim aligned as accurately as possible with the soil surface, creating a runoff catchment area of $64 \mathrm{~cm}^{2}$. Each bottle contained a sack of cheesecloth to catch displaced soil (particles $>2 \mathrm{~mm}$ ) and drain rainwater. These traps were checked and emptied after each rainfall event, and the collected soils from the traps were oven-dried $\left(105^{\circ} \mathrm{C}\right.$ for $\left.48 \mathrm{~h}\right)$ and weighed thereafter. The traps were regularly re-aligned with the soil surface after each rain shower by pressing them deeper into the soil whenever necessary. The traps were deep enough to ensure runoff charges never exceeded the trap volume during the time period of measurements. 
After the cereal crop harvest of the last season (May 2015), soil samples were taken from each plot to assess bulk density and soil fertility. Nine cylinders were collected at $0-5$ and 5$10 \mathrm{~cm}$ with $98.12-\mathrm{cm}^{3}$ cores and three cylinders at $10-20 \mathrm{~cm}$ with $785-\mathrm{cm}^{3}$ cores, and then weighed. For each depth independently, the samples were then mixed and $50 \mathrm{~g}$ was dried at $105{ }^{\circ} \mathrm{C}$ to determine soil water content. This value was then used to determine the dry weight of the bulk samples and hence dry bulk density. The remaining soil was dried and sieved (at $2 \mathrm{~mm}$ ) for organic carbon $\left(\mathrm{C}_{\text {org: }}\right.$ : Walkley-Black), nitrogen extraction $\left(\mathrm{N}_{\text {tot }}\right.$; Kjeldahl), available phosphorus $\left(\mathrm{P}_{\mathrm{Olsen}}\right)$ and $\mathrm{pH}\left(\mathrm{H}_{2} \mathrm{O}\right)$ analyses. Data are presented as aggregated for the layer $0-20 \mathrm{~cm}$ based on soil concentration values as bulk densities were similar among depths and treatments.

\subsection{Statistical analyses}

The residuals of all variables were checked for homoscedasticity and normality. Crop grain and biomass weight per year and cropping practice were subjected to ANOVA, following a mixed model, when there was a significant treatment (cropping practice) $\times$ year effect; means were compared following Tukey's honest significant difference test. Although the same plots received the same crop every 2 years, we did not consider a correlation structure for crop grain and biomass weight.

To test the 4-year treatment (cropping practice) effects on soil fertility $(0-20 \mathrm{~cm})$, values of bulk density, $\mathrm{C}_{\mathrm{org}}, \mathrm{N}_{\text {tot }}$, $\mathrm{P}_{\text {Olsen }}$ and $\mathrm{pH}$ from the parallel rice and the maize plots of year 4 of the same treatment were combined and averaged per replicate and subjected to ANOVA, followed by comparison of means. Pearson correlation analyses were used to examine the correlation between soil fertility parameters $\left(\mathrm{C}_{\mathrm{org}}\right.$, $\mathrm{N}_{\text {tot }}, \mathrm{P}_{\text {Olsen }}, \mathrm{pH}$ ) and rice and maize grain yields. Kendall correlation analysis was used to examine the correlation between the soil erosion and living mulch biomass production in year 3. Based on S. asiatica counts at 70, 90 and 110 DAS, the maximum aboveground Striga numbers $\left(\mathrm{NS}_{\max }\right)$ were calculated and used for correlation analyses. Pearson correlation analyses were used to examine the correlation between $\mathrm{NS}_{\max }$ and rice and maize grain yields.

All analyses were performed in R 3.4.1 (R Core Team 2017), using the lme4 package (Bates et al. 2015) for the ANOVAs.

\section{Results and discussion}

\subsection{Influence of CA practices and cover crop identity on rice production}

Rice grain yield and stover (straw) biomass were subject to significant year $\times$ cropping practice interaction effects
(ANOVA $P<0.0001$, Table 1). Analyses per year revealed significant cropping practice effects on rice grain yield and stover biomass in years 2 and 3 but not in years 1 and 4 . Across practices, rice yields in year 1 and 4 were around $2 \mathrm{t} /$ ha (Fig. 2a). In year 2 , the mean rice yield of CAST $(0.7 \mathrm{t} / \mathrm{ha})$ was significantly lower than those of CACM (2.9 t/ha, Tukey $P<0.0001)$ and CARB ( $2.5 \mathrm{t} / \mathrm{ha}, P=0.0002)$, but not CONV $(1.8 \mathrm{t} / \mathrm{ha}, P>0.5)$. In year 3 , the mean rice yield of CAST $(4.1 \mathrm{t} / \mathrm{ha})$ was significantly higher than those of CONV (1.8 t/ha, $P<0.0001)$ and CARB $(2.4 \mathrm{t} / \mathrm{ha}, P=0.0011)$, while yields of CACM $(3.2 \mathrm{t} / \mathrm{ha})$ were significantly higher $(P=$ 0.009 ) than those of CONV (Fig. 2a). Yields obtained from CONV plots were low but stable across years (ranging from 1.6 to $1.8 \mathrm{t} / \mathrm{ha}$ ). Rice stover production across cropping practices and years followed a similar trend as rice grain yields, except for year 3 where only CAST was significantly higher than CONV (Fig. 2b).

Averaged over 4 years, rice yields in this study ranged from $1.7 \mathrm{t} / \mathrm{ha}$ with conventional practice to $2.2 \mathrm{t}$ /ha with CARB and CAST and $2.5 \mathrm{t} / \mathrm{ha}$ with CACM. These yields all fall in the range of the region-wide average upland rice yields (1.0 to $2.5 \mathrm{t} / \mathrm{ha}$; Tanaka et al. 2017). Contrary to previous studies done in Madagascar (Dusserre et al. 2012), short-term yield benefits of CA practices did emerge in the current study. Particularly, in the CACM treatment, the cumulative rice production over the 4 years was significantly higher than in CONV $(9.8 \mathrm{t} / \mathrm{ha}$ vs $6.8 \mathrm{t} / \mathrm{ha}$ ), while the other CA practices resulted in cumulative yields similar to CONV. Rice yields seemed less stable with CA practices than with the conventional one, in particular following the CAST practice. In another recent study conducted in Madagascar, annual variations in rice yields were observed to be slightly reduced by following CA practices (Bruelle et al. 2015). This apparent contradiction could be explained by the absence of legume crops growing simultaneously with rice in the CA practices studied by Bruelle et al. (2015), whereas in the current study, the main contributor to the observed yield variability of CA was the highly competitive stylosanthes which was intercropped with rice.

The dramatic drop in rice yield with stylosanthes (CAST) in the second year (Fig. 2a) was caused by severe interspecific competition from the steeply increased stylosanthes biomass, while increases in soil nitrogen-observed in year 4; see Section 3.3-may not yet have been attained by that time. Stylosanthes produces high amounts of biomass, and therefore requires careful management when intercropped with a cereal crop. This is particularly true for rice, which is a weak competitor (van Heemst 1985), while interspecific competition is particularly important in the context of this field study, where low nutrient additions were made using poor-quality manure, considering that only a proportion of the nutrients get mineralized in the first year of application. Rice yield reduction in the first year of stylosanthes intercropping as reported by Saito et al. (2006) was not observed in the current study, probably 
Table 1 Analyses of variance of the effect of years (Y) and cropping practices $(\mathrm{CP})$ on rice yield and straw biomass, maize yield and maize-legume biomass. Mean square (MS), degrees of freedom (df), $F$ and $P$ values

\begin{tabular}{|c|c|c|c|c|c|c|}
\hline \multicolumn{7}{|l|}{ ANOVA } \\
\hline Variable & & Source & df & MS & $F$ & $P$ \\
\hline \multirow[t]{3}{*}{ Rice yield } & & Year (Y) & 3 & 5.71 & 16.78 & $<0.0001$ \\
\hline & & $\mathrm{CP}$ & 3 & 2.33 & 6.85 & 0.0005 \\
\hline & & $\mathrm{Y} * \mathrm{CP}$ & 9 & 3.18 & 9.35 & $<0.0001$ \\
\hline \multirow{3}{*}{\multicolumn{2}{|c|}{ Rice stover }} & $\mathrm{Y}$ & 3 & 7.61 & 34.94 & $<0.0001$ \\
\hline & & $\mathrm{CP}$ & 3 & 3.11 & 14.26 & $<0.0001$ \\
\hline & & $\mathrm{Y} * \mathrm{CP}$ & 9 & 3.63 & 16.64 & $<0.0001$ \\
\hline \multirow{3}{*}{\multicolumn{2}{|c|}{ Maize yield }} & $\mathrm{Y}$ & 3 & 3.96 & 26.26 & $<0.0001$ \\
\hline & & $\mathrm{CP}$ & 3 & 1.20 & 7.96 & 0.0001 \\
\hline & & $\mathrm{Y} * \mathrm{CP}$ & 9 & 0.27 & 1.79 & 0.09 \\
\hline \multirow{3}{*}{\multicolumn{2}{|c|}{$\begin{array}{l}\text { Maize }+ \text { cover } \\
\text { crop biomass }\end{array}$}} & $\mathrm{Y}$ & 3 & 155.62 & 41.79 & $<0.0001$ \\
\hline & & $\mathrm{CP}$ & 3 & 485.47 & 130.37 & $<0.0001$ \\
\hline & & $\mathrm{Y} * \mathrm{CP}$ & 9 & 121.15 & 32.53 & $<0.0001$ \\
\hline \multicolumn{7}{|l|}{ ANOVA by year } \\
\hline \multirow[t]{4}{*}{ Rice yield } & $\mathrm{Y} 1$ & $\mathrm{CP}$ & 3 & 0.10 & 0.53 & 0.67 \\
\hline & $\mathrm{Y} 2$ & & & 5.55 & 36.08 & $<0.0001$ \\
\hline & $\mathrm{Y} 3$ & & & 5.82 & 7.66 & 0.0025 \\
\hline & Y4 & & & 0.41 & 1.56 & 0.24 \\
\hline \multirow[t]{4}{*}{ Rice stover } & Y1 & $\mathrm{CP}$ & 3 & 0.03 & 0.24 & 0.87 \\
\hline & $\mathrm{Y} 2$ & & & 12.49 & 64.35 & $<0.0001$ \\
\hline & $\mathrm{Y} 3$ & & & 1.29 & 3.56 & 0.04 \\
\hline & Y4 & & & 0.17 & 0.95 & 0.44 \\
\hline \multirow{4}{*}{$\begin{array}{l}\text { Maize - cover } \\
\text { crop biomass }\end{array}$} & $\mathrm{Y} 1$ & $\mathrm{CP}$ & 3 & 16.11 & 7.43 & 0.0028 \\
\hline & $\mathrm{Y} 2$ & & & 631.53 & 167.25 & $<0.0001$ \\
\hline & $\mathrm{Y} 3$ & & & 157.66 & 18.72 & $<0.0001$ \\
\hline & Y4 & & & 43.61 & 82.70 & $<0.0001$ \\
\hline
\end{tabular}

because stylosanthes did not produce much biomass during the first cropping season.

\subsection{Influence of CA practices and cover crop identity on maize production}

Significant year $(P<0.0001)$ and cropping practice $(P=$ $0.0001)$ main effects, but no significant interactions, were observed on maize grain yields (Table 1). Maize yields were very low throughout the years and across management practices with no consistent yield benefits by any of the CA practices compared to the conventional practice. Average maize grain yields in this study were $0.4 \mathrm{t} / \mathrm{ha}$ and $0.5 \mathrm{t} / \mathrm{ha}$ under CAST and CACM, respectively, which were significantly lower than the $0.8 \mathrm{t} /$ ha obtained under both CONV and CARB. Maize yields were particularly low in the first 3 years, with averages across cropping practices of 0.45 (year 1), 0.41 (year 2), 0.38 (year 3) and 1.2 (year 4 ) $\mathrm{t} / \mathrm{ha}$. Maize yields were exceptionally low under CACM in year 1,2 and 3, while no maize yields were obtained under CAST in year 2 and 3 (Fig. 3a). Over the years, maize yields gradually increased in CACM and CARB plots, but fluctuated in CAST and CONV (Fig. 3a).
Even in the best year (year 4), maize yields hardly reached the level of the region-wide average of 1.2-2.2 $\mathrm{t} / \mathrm{ha}$ reported by van Ittersum et al. (2016). Higher maize yields in year 4 could be explained by markedly higher rainfall totals in months of vegetative growth (see Randrianjafizanaka et al. 2018). The extremely low grain yield average of maize intercropped with stylosanthes (CAST) was caused by (near) complete crop failure in year 2 and 3 . These years were very prolific in terms of stylosanthes biomass (Fig. 3b), and the observed reduced maize grain yields can therefore be explained by severe competition from the cover crop, especially under such poor soils with extremely low external inputs.

Crop yields are an important determinant for smallholder farmer adoption of new strategies such as conservation agriculture (e.g. Pannell et al. 2014). In the current study, CA practices with legumes as cover crops generally resulted in lower or equal maize yields and higher but more variable rice yields compared to the conventional practice. Grain legume cover crops produced very little grains (cowpea, 0.09-0.19 t/ ha; ricebean, $0-0.022 \mathrm{t} / \mathrm{ha}$; data not shown).

Crop residue biomass derived from the maize plots (i.e. maize stover in CONV, maize stover and cover crops in CACM, 
Fig. 2 Rice grain yield (a) and straw biomass (b), in tha, following different cropping practices in each of the experimental years (year 1-year 4). Within each year, boxes with different letters are significantly different $(P<0.05)$. Black dots in the boxes indicate treatment means. CACM, rice + maize/ cowpea/mucuna; CARB, rice + maize/ricebean; CAST, rice/stylosanthes + maize/ stylosanthes; CONV, rice + maize (conventional practice)
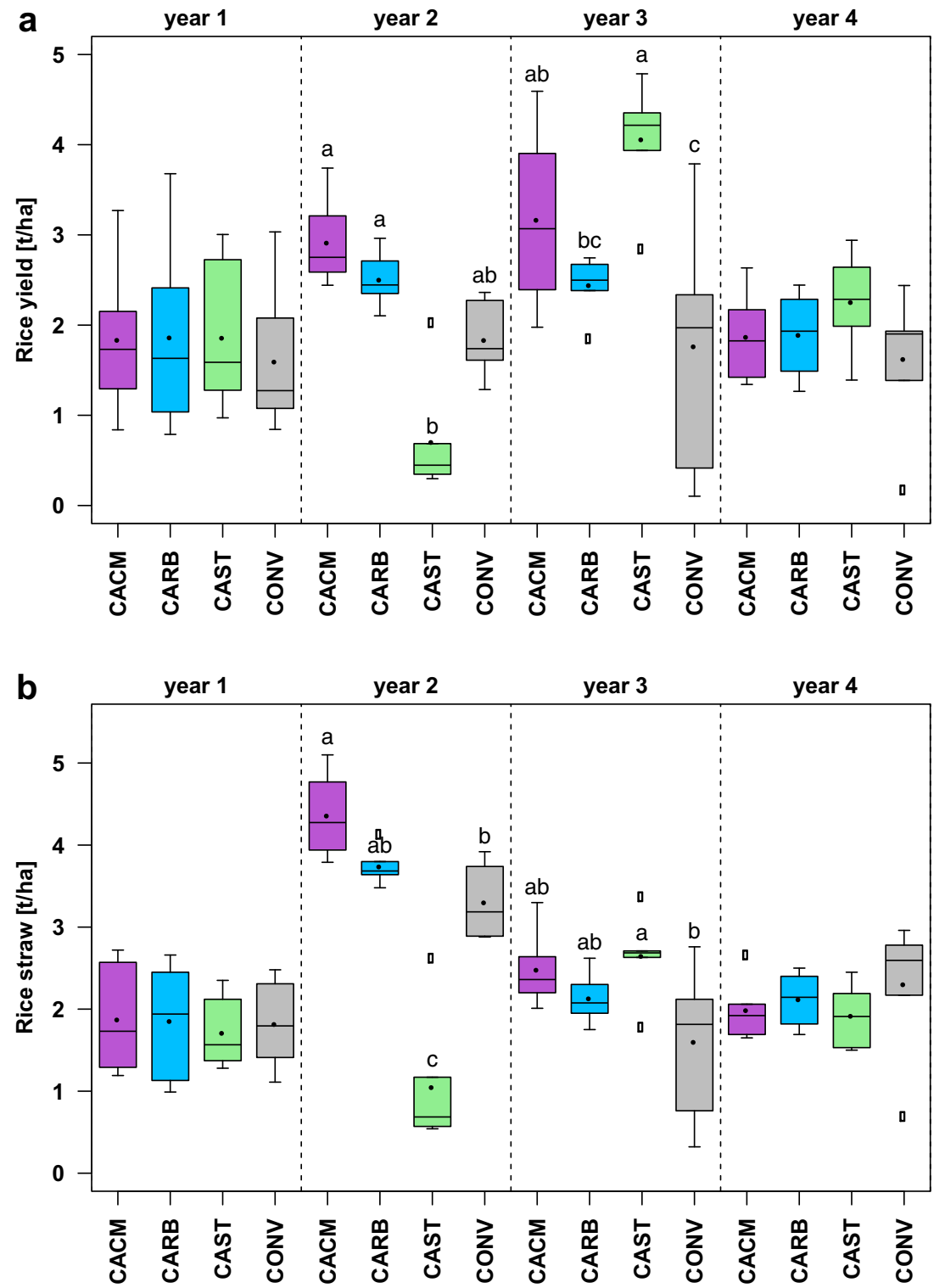

CARB and CAST) was subject to significant year $\times$ cropping practice interaction effects $(P<0.0001$, Table 1$)$. Analyses per year revealed significant cropping practice effects on crop residue biomass in all years (Y1: $P=0.0028$; Y2-4: $P<0.0001$ ). Like maize grain yields, the crop residue biomass was variable throughout seasons and practices, ranging from $1.3 \mathrm{t} / \mathrm{ha}$, under CONV in year 3 , to as high as $23.7 \mathrm{t} / \mathrm{ha}$, under CAST in year 2 (Fig. 3b). In year 1, the highest crop biomass production was attained with $\mathrm{CARB}$, marginally significantly different from CACM $(P=0.11)$. From the second year onwards, biomass of CAST was always significantly higher $(P<0.0001$ in year 2 and $3 ; P<0.01$ in year 4$)$ than that of any other cropping practice, and there were no significant differences between the other three practices (Fig. 3b). Crop biomass production is an important objective of $\mathrm{CA}$, and the lack thereof is considered one of the main constraints to widespread adoption among smallholder farmers in SSA (Erenstein 2002). Biomass serves the soil conservation objective - see Section 3.3- but is also used as fodder. On mixed crop-livestock farms, competing claims on crop residue biomass may arise (Baudron et al. 2015). Among the cover crops included in the current study, stylosanthes would best address this concern, as it produced the highest amounts of biomass. But even the biomass produced by this multipurpose crop would not be enough to do both, i.e. feeding cattle and providing the necessary $95 \%$ of soil coverage to satisfy soil conservation and weed control functions (Naudin et al. 2015).

\subsection{Influence of CA practices and cover crop identity on soil erosion and fertility}

The combination of cover crops and no till significantly reduced soil erosion compared to the conventional practice $(F=$ 17.79; $P<0.0001)$, as observed during nine mid-season weeks in year 3 (following $444 \mathrm{~mm}$ rainfall). Under CONV, 
Fig. 3 Maize grain yield (a) and maize-legume stover (straw) biomass (b), in t/ha, following different cropping practices, in each of the experimental years (year 1-year 4). For maize yield, years (see top) and practices (see legend) with different letters indicate significantly different grain yields $(P<0.05)$. Within each year, boxes with different letters indicate significantly different biomass production $(P<0.05)$. Black dots in the boxes indicate treatment means. CACM, rice + maize/cowpea/ mucuna; CARB, rice + maize/ ricebean; CAST, rice/stylosanthes + maize/stylosanthes; CONV, rice

+ maize (conventional practice)
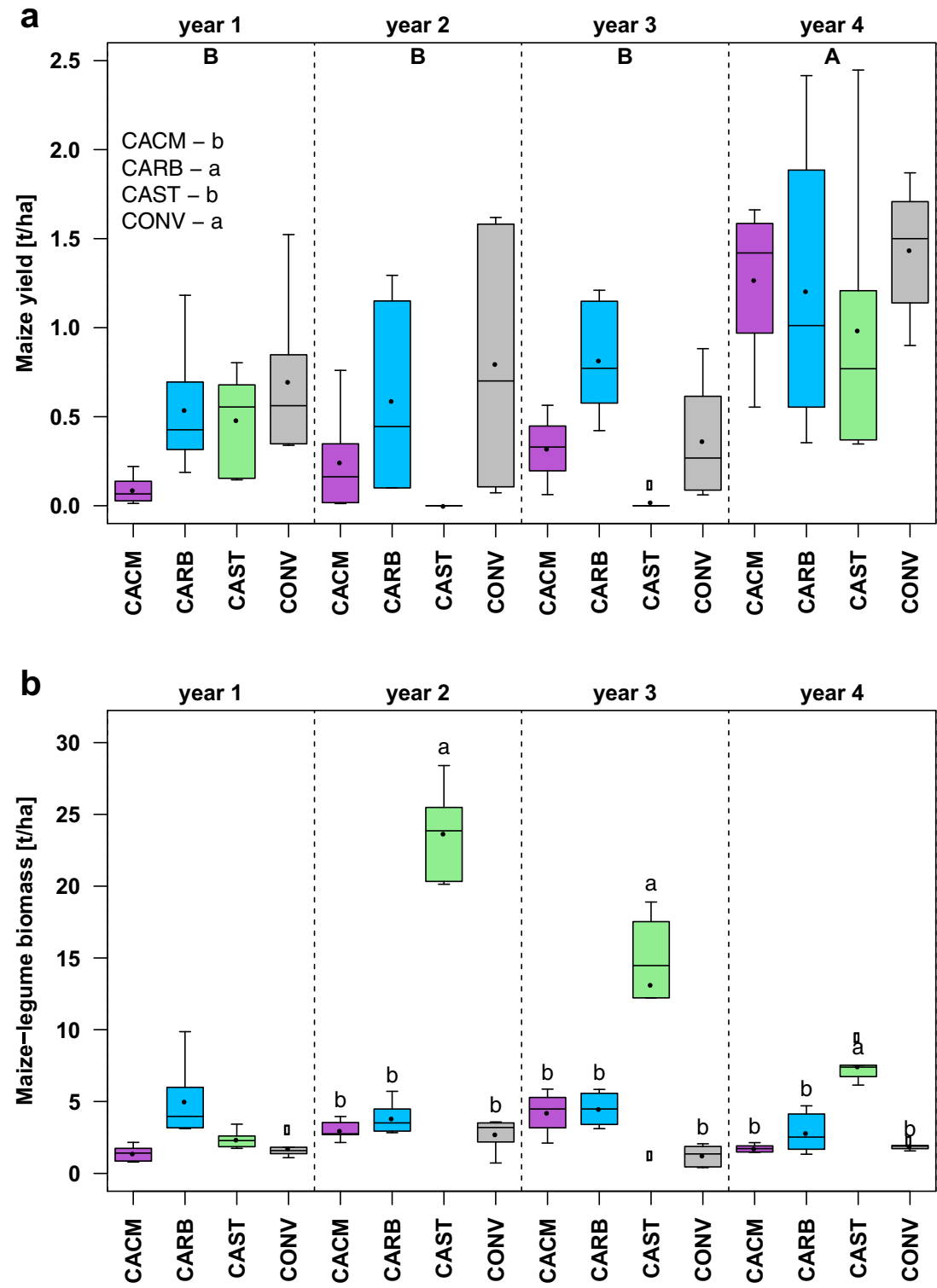

on average, $421 \mathrm{~g}$ of soil was captured per trap, while under CARB, this was only $92 \mathrm{~g}$ of soil per trap, and with CAST, this was further reduced to $2 \mathrm{~g}$ per trap (data not shown). There were no significant differences between CARB and CAST $(P=0.457)$. A highly significant negative correlation (Kendall) was observed between crop residue production in year 3 and soil erosion rates $(\tau=-0.53 ; P=0.00167)$. This confirms earlier studies showing that the effectiveness of mulch as a soil conservation measure depends on the amount of biomass (e.g. Erenstein 2002).

After 4 years of treatments, bulk density (not shown), soil organic carbon concentration and available phosphorus were not different between cropping practices (Fig. 4). Cropping practice had a significant $(P<0.05)$ effect on soil total nitrogen and $\mathrm{pH}$. Pairwise comparisons showed that CAST resulted in a significantly higher soil total nitrogen concentration $(P=0.02)$ and $\mathrm{pH}(P=0.009)$ than CONV.
Based on criteria established by Sahrawat et al. (2001) and Ussiri et al. (1998), soils of the present experimental field are $\mathrm{P}$ deficient for both rice and maize respectively (range, 1.8$3.0 \mathrm{mg} / \mathrm{kg}$; in year 4, 0-20 cm). In the current study, no significant cropping practice effects on available soil phosphorus $\left(\mathrm{P}_{\text {Olsen }}\right)$ were observed after 4 years despite a different treatment in crop residues. Possibly, the soil-extracted phosphorus fixed in dead or living biomass in CA plots had not yet returned to the soil after 4 years.

Compared to the conventional rice-maize rotation (CONV), the combination of no till, stylosanthes intercropping and crop residue mulching (CAST) led to a significantly higher total soil$\mathrm{N}$ concentration over time, probably because of the species capacity of biological nitrogen fixation combined with the high biomass production. This confirms a previous study conducted in the same area, showing that intercropping with $S$. guianensis improved nitrogen supply to rice (Zemek et al. 2018), despite the 
Fig. 4 Soil fertility parameters (organic carbon, total nitrogen, available phosphorus and $\mathrm{pH}$ ) of the upper $20 \mathrm{~cm}$, following different cropping practices after 4 years of experimentation. Boxes with different letters are significantly different $(P<0.05)$. Black dots in the boxes indicate treatment means. CACM, rice + maize/cowpea/mucuna; CARB, rice + maize/ricebean; CAST, rice/stylosanthes + maize/ stylosanthes; CONV, rice + maize (conventional practice) a

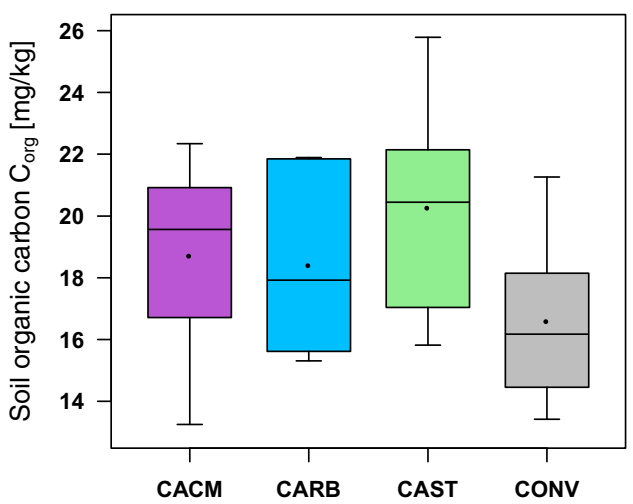

C

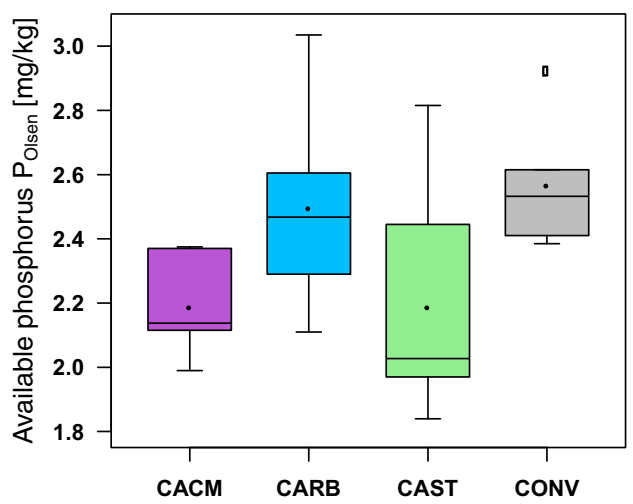

b

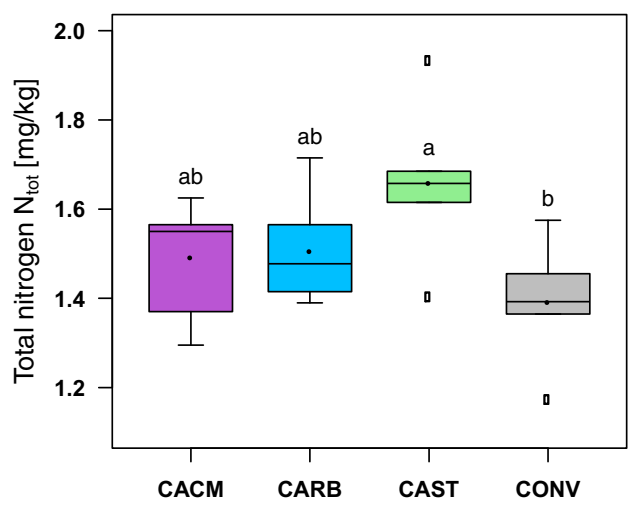

d

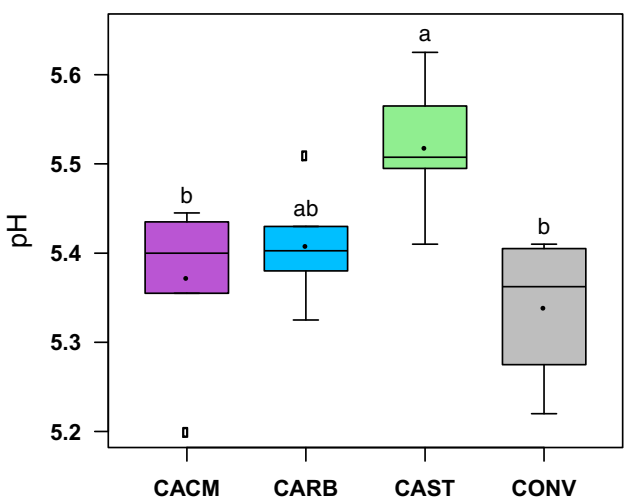

prevailing soil P deficiencies. Indeed, soil nitrogen concentration can be significantly improved when residues from legumes are not removed from the field (Vanlauwe and Giller 2006). The soil $\mathrm{pH}$ has also significantly increased with CAST, which is another important benefit on acidic tropical soils, and a prerequisite for improved overall soil fertility (e.g. Fageria and Baligar 2003).

Adoption rates of technologies by smallholder farmers in the tropics are a function of their short-term benefits (Pannell et al. 2014), and this requirement may be another important hurdle for CA adoption. While consistent yield advantages from CA emerge only slowly (e.g. Swanepoel et al. 2018; Rusinamhodzi et al. 2011), particularly on degraded soils (Giller et al. 2011), other benefits, such as soil conservation or fodder production, are delivered immediately and may convince farmers to indeed adopt this kind of practices despite the moderate and slow yield improvements. Bruelle et al. (2015) also observed that CA practices may provide farmers in Madagascar with a wider crop establishment window, which may be an important additional advantage for smallholders in rain-fed uplands. Whether the soil fertility and conservation benefits observed in the current study, and the possible additional advantages observed by others, will outweigh the additional costs for labour and crop seeds and compensate for absent or slow yield increases in maize will depend on the farmer's main production objectives and concerns (Corbeels et al. 2014) and possibly on specific, local or temporal environmental conditions (Swanepoel et al. 2018).

\subsection{Correlation between crop production and soil fertility or Striga infestation}

No significant correlations between any soil fertility parameter and rice yields were observed, but (marginally) significant positive correlations between maize yield and $C_{\text {organic }}(\rho=0.40, P=$ $0.052)$ or $P_{\text {Olsen }}(\rho=0.52, P=0.010)$ and a significant negative correlation $(\rho=-0.41, P=0.048)$ between maize yield and $\mathrm{pH}$ occurred. The correlation of maize yield with soil fertility parameters supports previous suggestions by Vanlauwe et al. (2014) that additional fertilizer application would be a necessary element of CA, to ensure that sustainability and profitability go hand in hand. Contrary to findings by Masvaya et al. (2017) with maize-cowpea intercropping, the yields in the current study were generally not improved and were often even reduced when maize was intercropped with a legume, despite improvements in soil nitrogen concentration compared to conventional practice (measured after 4 years). Poor soil fertility and low addition of nutrients through poor-quality manure, in combination with increased interspecific competition, may have masked the positive effects of cover crops on maize yields. Poor soils have previously been suggested to limit production of crop residues and thereby constrain the success of CA practices (Giller et al. 2011).

The analyses showed a significant positive correlation between maximum aboveground $S$. asiatica plant numbers $\left(N S_{\max }\right)$ and rice grain yield in year $1(\rho=0.54, P=0.006)$ 
and significant negative correlations in year $3(\rho=-0.51, P=$ $0.011)$ and $4(\rho=-0.53, P=0.007)$, while no significant correlation was observed between $N S_{\max }$ and maize grain yields in any year. Based on the correlation analyses, Striga asiatica infection was an important yield-determining factor in rice. The positive correlation between $S$. asiatica and rice yield in year 1 , and the absence of any correlation in year 2 , can probably be explained by the low $S$. asiatica infection levels in those years. Under low Striga infection levels, a correlation analysis is more sensitive to confounding factors such as soil fertility. In years with higher $S$. asiatica infection levels (year 3 and 4), a significant negative correlation with rice yield was observed. Infestation levels of Striga spp. often show important annual variation (e.g. Rodenburg et al. 2017). The overall low to moderate level of infection may explain the absence of correlations between $S$. asiatica and maize yield in any year. The difference between the yield-reducing $S$. asiatica effects on maize and rice in this study may reflect a difference in resistance and tolerance. While we have no information on the resistance or tolerance of maize variety IRAT 200, rice variety B22 is known to be susceptible (Randrianjafizanaka et al. 2018).

This is the first study to show that under Striga-infested conditions, there are a number of positive outcomes from CA (i.e. on rice yields and soil conservation, nitrogen and $\mathrm{pH}$ ) alongside remaining concerns (i.e. poor maize and cover crop performance, low available soil $\mathrm{P}$ ).

\section{Conclusion}

A 4-year agronomic assessment provided relevant and novel insights in the merits and challenges of conservation agriculture $(\mathrm{CA})$ practices for smallholder rice-maize production systems with low external inputs, on degraded and Strigainfested soils. Medium-term benefits included moderate rice yield and soil nitrogen increments, and steep reductions in soil erosion. Rice yields were highest with CA using a maizemucuna-cowpea intercrop. In years with relatively high Striga asiatica infection levels, rice yield correlated negatively with parasitic weed density. Poor soil $\mathrm{N}$ content, acidity and soil erosion were best addressed by intercropping with stylosanthes. Low and variable maize yields were clear shortcomings of the CA practices tested here. There was a clear trade-off between maize yield and the biomass production of the perennial cover crop stylosanthes. A plausible cause for general low maize yields under all practices was poor soil fertility and low external input of nutrients, and this may have aggravated competition effects from cover crops in the CA practices. This is the first study showing that CA practices can contribute to improved upland rice yields under Strigainfested conditions, and that apart from additional positive soil nitrogen, $\mathrm{pH}$ and conservation outcomes, concerns remain to be addressed regarding poor maize yield and available soil phosphorus. Conservation agriculture practices on degraded Striga-infested tropical soils could possibly be improved by a combination of more frequent cover crop management interventions - to reduce interspecific competition with the main crop, targeted fertilizer applications (or increased manure quantity/quality) and the selection of more competitive, Striga-resistant and locally adapted crop varieties.

Acknowledgments We sincerely thank Roger Michellon (CIRAD) and Narcisse Moussa (GSDM) for their valuable contributions to the fieldwork. This study was funded by the CGIAR Research Program GRiSP (Global Rice Science Partnership) and the African Development Bank (AfDB) as part of the project "Support to Agricultural Research for Development of Strategic Crops in Africa (SARD-SC)".

\section{Compliance with ethical standards}

Conflict of interest The authors declare that they have no conflict of interest.

Open Access This article is licensed under a Creative Commons Attribution 4.0 International License, which permits use, sharing, adaptation, distribution and reproduction in any medium or format, as long as you give appropriate credit to the original author(s) and the source, provide a link to the Creative Commons licence, and indicate if changes were made. The images or other third party material in this article are included in the article's Creative Commons licence, unless indicated otherwise in a credit line to the material. If material is not included in the article's Creative Commons licence and your intended use is not permitted by statutory regulation or exceeds the permitted use, you will need to obtain permission directly from the copyright holder. To view a copy of this licence, visit http://creativecommons.org/licenses/by/4.0/.

\section{References}

Barthes B, Azontonde A, Blanchart E, Girardin C, Villenave C, Lesaint S, Oliver R, Feller C (2004) Effect of a legume cover crop (Mucuna pruriens var. utilis) on soil carbon in an Ultisol under maize cultivation in southern Benin. Soil Use Manag 20:231-239. https://doi.org/ 10.1111/j.1475-2743.2004.tb00363.x

Bates D, Mächler M, Bolker B, Walker S (2015) Fitting linear mixedeffects models using lme4. J Stat Softw 67:1-48. https://doi.org/10. 18637/jss.v067.i01

Baudron F, Delmotte S, Corbeels M, Herrera JM, Tittonell P (2015) Multi-scale trade-off analysis of cereal residue use for livestock feeding vs. soil mulching in the mid-Zambezi Valley. Zimbabwe Agr Syst 134:97-106. https://doi.org/10.1016/j.agsy.2014.03.002

Bruelle G, Naudin K, Scopel E, Domas R, Rabeharisoa L, Tittonell P (2015) Short- to mid-term impact of conservation agriculture on yield variability of upland rice: evidence from farmer's fields in Madagascar. Exp Agric 51:66-84. https://doi.org/10.1017/ s0014479714000155

Corbeels M, de Graaff J, Ndah TH, Penot E, Baudron F, Naudin K, Andrieu N, Chirat G, Schuler J, Nyagumbo I, Rusinamhodzi L, Traore K, Mzoba HD, Adolwa IS (2014) Understanding the impact and adoption of conservation agriculture in Africa: a multi-scale 
analysis. Agric Ecosyst Environ 187:155-170. https://doi.org/10. 1016/j.agee.2013.10.011

Dusserre J, Chopart JL, Douzet JM, Rakotoarisoa J, Scopel E (2012) Upland rice production under conservation agriculture cropping systems in cold conditions of tropical highlands. Field Crop Res 138: 33-41. https://doi.org/10.1016/j.fcr.2012.09.011

Erenstein O (2002) Crop residue mulching in tropical and semi-tropical countries: an evaluation of residue availability and other technological implications. Soil Till Res 67:115-133. https://doi.org/10.1016/ S0167-1987(02)00062-4

Fageria NK, Baligar VC (2003) Fertility management of tropical acid soil for sustainable crop production. In: Rengel Z (ed) Handbook of soil acidity. Marcel Dekker, Inc., New York, pp 359-386

Giller KE, Corbeels M, Nyamangara J, Triomphe B, Affholder F, Scopel E, Tittonell P (2011) A research agenda to explore the role of conservation agriculture in African smallholder farming systems. Field Crop Res 124:468-472. https://doi.org/10.1016/j.fcr.2011.04.010

Masvaya EN, Nyamangara J, Descheemaeker K, Giller KE (2017) Is maize-cowpea intercropping a viable option for smallholder farms in the risky environments of semi-arid southern Africa? Field Crop Res 209:73-87. https://doi.org/10.1016/j.fcr.2017.04.016

Naudin K, Bruelle G, Salgado P, Penot E, Scopel E, Lubbers M, de Ridder N, Giller KE (2015) Trade-offs around the use of biomass for livestock feed and soil cover in dairy farms in the Alaotra lake region of Madagascar. Agric Syst 134:36-47. https://doi.org/10. 1016/j.agsy.2014.03.003

Nhamo N, Rodenburg J, Zenna N, Makombe G, Luzi-Kihupi A (2014) Narrowing the rice yield gap in east and southern Africa: using and adapting existing technologies. Agric Syst 131:45-55. https://doi. org/10.1016/j.agsy.2014.08.003

Pannell DJ, Llewellyn RS, Corbeels M (2014) The farm-level economics of conservation agriculture for resource-poor farmers. Agric Ecosyst Environ 187:52-64. https://doi.org/10.1016/j.agee.2013.10.014

R Core Team (2017) R: a language and environment for statistical computing. R Foundation for Statistical Computing Vienna, Vienna

Ranaivoson L, Naudin K, Ripoche A, Rabeharisoa L, Corbeels M (2019) Effectiveness of conservation agriculture in increasing crop productivity in low-input rainfed rice cropping systems under humid subtropical climate. Field Crop Res 239:104-113. https://doi.org/10. 1016/j.fcr.2019.05.002

Randrianjafizanaka MT, Autfray P, Andrianaivo AP, Ramonta IR, Rodenburg J (2018) Combined effects of cover crops, mulch, zero-tillage and resistant varieties on Striga asiatica (L.) Kuntze in rice-maize rotation systems. Agric Ecosyst Environ 256:23-33. https://doi.org/10.1016/j.agee.2017.12.005

Rodenburg J, Stein A, Noordwijk M, Ketterings QM (2003) Spatial variability of soil $\mathrm{pH}$ and phosphorus in relation to soil runoff following slash-and-burn land clearing in Sumatra. Indonesia Soil Till Res 71: 1-14. https://doi.org/10.1016/S0167-1987(02)00141-1

Rodenburg J, Demont M, Zwart SJ, Bastiaans L (2016) Parasitic weed incidence and related economic losses in rice in Africa. Agric Ecosyst Environ 235:306-317. https://doi.org/10.1016/j.agee.2016. 10.020

Rodenburg J, Cissoko M, Kayongo N, Dieng I, Bisikwa J, Irakiza R, Masoka I, Midega CAO, Scholes JD (2017) Genetic variation and host-parasite specificity of Striga resistance and tolerance in rice: the need for predictive breeding. New Phytol 214:1267-1280. https:// doi.org/10.1111/nph.14451

Rusinamhodzi L, Corbeels M, van Wijk MT, Rufino MC, Nyamangara J, Giller KE (2011) A meta-analysis of long-term effects of conservation agriculture on maize grain yield under rain-fed conditions. Agron Sustain Dev 31:657-673. https://doi.org/10.1007/s13593011-0040-2

Rusinamhodzi L, Corbeels M, Nyamangara J, Giller KE (2012) Maizegrain legume intercropping is an attractive option for ecological intensification that reduces climatic risk for smallholder farmers in central Mozambique. Field Crop Res 136:12-22. https://doi.org/10. 1016/j.fcr.2012.07.014

Sahrawat KL, Jones MP, Diatta S, Adam A (2001) Response of upland rice to fertilizer phosphorus and its residual value in an ultisol. Commun Soil Sci Plan 32:2457-2468. https://doi.org/10.1081/ CSS-120000384

Saito K, Linquist B, Keobualapha B, Phanthaboon K, Shiraiwa T, Horie T (2006) Stylosanthes guianensis as a short-term fallow crop for improving upland rice productivity in northern Laos. Field Crop Res 96:438-447. https://doi.org/10.1016/j.fcr.2005.09.005

Schuller P, Walling DE, Sepulveda A, Castillo A, Pino I (2007) Changes in soil erosion associated with the shift from conventional tillage to a no-tillage system, documented using (CS)-C-137 measurements. Soil Till Res 94:183-192. https://doi.org/10.1016/j.still.2006.07.014

Seck PA, Diagne A, Mohanty S, Wopereis MCS (2012) Crops that feed the world 7: Rice. Food Sec 4:7-24. https://doi.org/10.1007/s12571012-0168-1

Shiferaw B, Prasanna BM, Hellin J, Banziger M (2011) Crops that feed the world 6. Past successes and future challenges to the role played by maize in global food security. Food Sec 3:307-327. https://doi. org/10.1007/s12571-011-0140-5

Swanepoel CM, Rötter RP, van der Laan M, Annandale JG, Beukes DJ, du Preez CC, Swanepoel LH, van der Merwe A, Hoffmann MP (2018) The benefits of conservation agriculture on soil organic carbon and yield in southern Africa are site-specific. Soil Tillage Res 183:72-82. https://doi.org/10.1016/j.still.2018.05.016

Tanaka A, Johnson J-M, Senthilkumar K, Akakpo C, Segda Z, Yameogo LP, Bassoro I, Lamare DM, Allarangaye MD, Gbakatchetche H, Bayuh BA, Jaiteh F, Bam RK, Dogbe W, Sékou K, Rabeson R, Rakotoarisoa NM, Kamissoko N, Mossi IM, Bakare OS, Mabone FL, Gasore ER, Baggie I, Kajiru GJ, Mghase J, Ablede KA, Nanfumba D, Saito K (2017) On-farm rice yield and its association with biophysical factors in sub-Saharan Africa. Eur J Agron 85:111. https://doi.org/10.1016/j.eja.2016.12.010

Ussiri DA, Mnkeni PNS, MacKenzie AF, Semoka JMR (1998) Soil test calibration studies for formulation of phosphorus fertilizer recommendations for maize in Morogoro district, Tanzania. I Evaluation of soil test methods. Commun Soil Sci Plan 29:2801-2813. https:// doi.org/10.1080/00103629809370155

van Heemst HDJ (1985) The influence of weed competition on crop yield. Agr Syst 18:81-93. https://doi.org/10.1016/0308-521X(85) 90047-2

van Ittersum MK, van Bussel LGJ, Wolf J, Grassini P, van Wart J, Guilpart N, Claessens L, de Groot H, Wiebe K, Mason-D'Croz D, Yang HS, Boogaard H, van Oort PAJ, van Loon MP, Saito K, Adimo O, Adjei-Nsiah S, Agali A, Bala A, Chikowo R, Kaizzi K, Kouressy M, Makoi J, Ouattara K, Tesfaye K, Cassman KG (2016) Can subSaharan Africa feed itself? P Natl Acad Sci USA 113:14964-14969. https://doi.org/10.1073/pnas.1610359113

Vanlauwe B, Giller KE (2006) Popular myths around soil fertility management in sub-Saharan Africa. Agric Ecosyst Environ 116:34-46. https://doi.org/10.1016/j.agee.2006.03.016

Vanlauwe B, Wendt J, Giller KE, Corbeels M, Gerard B, Nolte C (2014) A fourth principle is required to define conservation agriculture in sub-Saharan Africa: the appropriate use of fertilizer to enhance crop productivity. Field Crop Res 155:10-13. https://doi.org/10.1016/j. fcr.2013.10.002

Zemek O, Frossard E, Scopel E, Oberson A (2018) The contribution of Stylosanthes guianensis to the nitrogen cycle in a low input legumerice rotation under conservation agriculture. Plant Soil 425:553576. https://doi.org/10.1007/s11104-018-3602-0

Publisher's note Springer Nature remains neutral with regard to jurisdictional claims in published maps and institutional affiliations. 